\title{
Venäjä-yhteistyön intressit ja ristiriidat
}

Syyskuun alussa 2019 ulkoministeri Pekka Haaviston Financial Timesille antama haastattelu on nostattanut jälleen keskustelua Suomen ja Venäjän suhteista, Euroopan unionin yhteisestä ulko- ja turvallisuuspolitiikasta sekä unionin suhtautumisesta kansainvälisiä säännöksiä rikkovaan Venäjään. Erityisesti kritiikkiä on saanut ministerin lausunto, jossa korostettiin hyvien suhteiden merkitystä ja Venäjän keskeistä roolia kansainvälisten konfliktien ratkaisussa. Alkukesästä useissa Euroopan maissa ihmeteltiin Euroopan neuvoston päätöstä ottaa Venäjä neuvoston täysivaltaiseksi jäseneksi, vaikka Venäjän johto ei ollut antanut periksi missään niistä asioista, joiden takia äänioikeus alun perin jäädytettiin.

Edellä mainitut esimerkit osoittavat, että Suomen tai Euroopan unionin Venäjä-suhteet eivät ole yksiviivaiset. Monissa maissa Venäjään ja Venäjä-yhteistyöhön suhtaudutaan erittäin kriittisesti. Myös Suomi pitää kiinni EU:n Venäjä-politiikkaa ohjaavista viidestä periaatteesta ja Minskin sopimuksen noudattamiseen sidotusta pakotepolitiikasta. Kuten presidentti Sauli Niinistö ja ulkoministeriön viranomaiset ovat useita kertoja korostaneet, Venäjä-suhteet eivät ole "Business as usual" eikä Venäjän kanssa voi tapahtua suurempaa lähenemistä ennen kuin maan johto on halukas ratkaisemaan Ukrainaan liittyviä kynnyskysymyksiä. Krimin niemimaan valtaus ja Venäjän asevoimien sekaantuminen Ukrainan konfliktiin ovat kansainvälisen oikeuden loukkauksia, joita ei voi ohittaa olankohautuksella.

Toisaalta Suomi tukee unionin periaatetta, jonka mukaan kaikesta huolimatta on annettava mahdollisuus keskustelulle ja valikoivalle kanssakäymiselle Venäjän kanssa. On monia ympäristönsuojeluun, rajan toimintaan, kansalaisyhteyksiin ja turvallisuuteen liittyviä käytännön kysymyksiä, jotka ovat ratkaistavissa vain avoimen dialogin avulla. Usein käytetty esimerkki avoimen vuoropuhelun merkityksestä on talvella 2015-2016 Pohjois-Venäjältä Sallan ja RajaJoosepin rajanylityspaikoilla tapahtuneet turvapaikanhakijoiden "laittomat rajanylitykset", jotka loppuivat aktiivisten virkamiestason neuvotteluiden ja presidentti Vladimir Putinin Venäjän turvallisuuspalvelulle pitämän puheen jälkeen helmikuun lopussa 2016. Tämän lisäksi kauppasuhteet, ostos- ja liikematkailijoiden sekä tavaroiden rajanylitysten sujuvuus, kuin myös paikallistason rajat ylittävä yhteistyö ovat Suomen talouden kannalta tärkeitä. Kauppa ja matkailu tuovat työtä kun taas rajat ylittävä yhteistyö tuo kaivattuja lisäresursseja alueiden talouteen ja kehittämiseen.

Rajat ylittävän yhteistyön merkitys korostuu erityisesti itärajan maakunnissa. Rajan avautuminen muutama vuosikymmen sitten toi mukanaan muun muassa monia rikollisuuteen ja maahanmuuttoon liittyviä uhkakuvia. Samalla itä antoi eri toimijoille uuden kansainvälistymisen suunnan. Nykypäivänä monilla paikallisen tason yrittäjillä, hallinnon ja kansalaisjärjestöjen edustajilla ja esimerkiksi kouluilla on jo vakiintuneet suhteet ja vuosien kokemus 
venäläisten kumppanien kanssa toimimisesta. Näille yhteistyö ei konkretisoidu hapantuneiden EU:n ja Venäjän välisten suhteiden kautta vaan todellisina voimavaroina. Siksi eri alojen toimijat myös iloitsevat siitä, että alueelliset ja rajat ylittävät yhteistyöohjelmat jäivät EU:n Venäjän vastaisten pakotteiden ulkopuolelle. Suhteiden heikentyminen ja pakotepolitiikka heijastuivat alueilla lähinnä ruplan arvon muutoksen sekä Euroopan unionin ja Venäjän välisten raja-alueohjelmien myöhästymisen kautta.

Suomen ulkoministeriön Itämeren, Barentsin ja arktisen alueen rajat ylittävään yhteistyöhön kohdistama rahoitus oli 1,8 miljoonaa euroa vuonna 2018. Suurin osa siitä käytettiin arktiseen yhteistyöhön ja konkreettisiin ympäristö-, turvallisuus- liikenne- ja terveysalojen hankkeisiin, joiden avulla pyritään vahvistamaan Itämeren ja arktisen alueen vakautta ja kestävää kehitystä. Rahoituksella tuetaan Suomen kansallisia tavoitteita Itämeren alueen yhteistyössä sekä Suomen arktisen strategian ja hallituksen Venäjä-politiikan toimeenpanoa. Kuten rajat ylittävässä yhteistyössä, alueellisella tasolla Itämeri-yhteistyössä, Barentsin yhteistyössä ja neljän tasavertaisen kumppanin (Euroopan unionin, Venäjän, Norjan ja Islannin) välisessä Pohjoisen ulottuvuuden yhteistyössä pyritään keskittymään käytännön hankkeisiin. Vaikka näillä eri toimijoilla olisikin kaikilla omanlaisiaan poliittisia paineita, kokouksien asialistoille tai neuvottelupöytiin ei nosteta poliittisesti arkoja aiheita. Esimerkiksi Pohjoisen ulottuvuuden neljän kumppanuuden (kulttuuri, ympäristö, liikenne ja logistiikka, sosiaali ja terveys) toiminnan lähtökohtana on yhteistyön käytännönläheisyys. Jos neuvottelupöydissä puhutaan oikeasti Euroopan unionin, sen jäsenmaiden ja Venäjän intresseissä olevista kysymyksistä, kuten kiertotaloudesta, luovien alojen mahdollisuuksista, ydinjätteistä, tai mustan hiilen vaikutuksista ilmastonmuutokseen, niin yhteisen näkemyksen tai jopa strategioiden luomisen odotetaan tässäkin poliittisessa tilanteessa olevan mahdollista.

Euroopan unionin jäsenmaiden, tai jopa yksittäisten poliitikkojen ja virkamiesten erilaiset käsitykset Venäjä-politiikan tavoitteista, pakotteiden tai valikoivan kanssakäymisen rajoista ja yhteistyön laajuudesta ja merkityksestä nostavat esiin kysymyksen EU:n yhteisen ulko- ja turvallisuuspolitiikan monitahoisuudesta. Yhtäältä Venäjä on keskeinen toimija niin Suomen kuin koko Euroopan kannalta. Siksi Venäjän jättäminen ulos kansainvälisistä neuvottelupöydistä ei varmasti edistä poliittista vuoropuhelua tai vaikkapa niin Suomelle kuin koko Euroopan unionille tärkeiden taloudellisten ja ympäristön tilaan liittyvien asioiden ratkaisua. Toisaalta Venäjän ottaminen mukaan kansainväliseen toimintaan täysivaltaisena toimijana tai poliittiset kysymykset sivuun jättävän, käytännönläheisen Venäjä-yhteistyön lisääminen ei voi johtaa Suomelle ja Euroopan unionille tärkeän, demokratian perinteisiin pohjautuvan arvopohjan hylkäämiseen. Kansainvälisten pakotteiden leimaama ajanjakso onkin osoittanut, että EUjäsenmaiden ja niiden eri toimijoiden kokemukset Venäjästä ovat kovin erilaisia. Dialogin ja valikoivan kanssakäymisen lisäksi olisi erittäin tärkeää säilyttää Euroopan unionin riittävä tuki käytännön rajat ylittävään ja alueelliseen Venäjä-yhteistyöhön myös tulevaisuudessa.

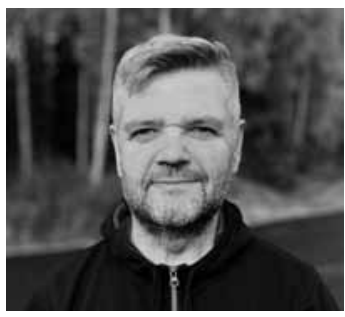

Joni Virkkunen

Kirjoittaja toimii tutkimuspäällikkönä Itä-Suomen yliopistossa. Hän on tutkinut Venäjän maahanmuuttoa, Euroopan unionin toimijuutta sekä Venäjän kanssa tehtävää alueellista ja rajat ylittävää yhteistyötä 